\title{
EFEKTIVITAS LATIHAN PERNAFASAN RELAKSASI TERHADAP KELELAHAN PADA PASIEN KANKER YANG MENJALANI KEMOTERAPI
}

\author{
[EFFECTIVENESS OF RELAXATION BREATHING EXERCISE TO FATIGUE IN CANCER \\ PATIENTS WHO UNDERGOING CHEMOTHERAPY ] \\ Vervando J. Sumilat ${ }^{1}$, Dewi Prabawati ${ }^{2}$, Sudibyo Supardi ${ }^{3}$ \\ Universitas KatolikDe La Salle Manado ${ }^{1}$ \\ STIK Sint Carolus Jakarta ${ }^{2}$ \\ Badan Penelitian dan Pengembangan Kesehatan $\mathrm{RI}^{3}$ \\ e-mail :vsumilat@unikadelasalle.ac.id \\ DOI : 10.47718/jpd.v8i01.1021
}

ABSTRAK
Latar Belakang : Pasien kanker dengan kemoterapi mengalami kelelahan karena efek penyakit kanker dan penghancuran sel-sel normal akibat toksisitas obat kemoterapi. Tujuan : Mengetahui efektivitas latihan pernafasan relaksasi terhadap kelelahan pasien kanker dengan kemoterapi. Metode : Penelitian ini menggunakan metode quasi experiment pretest and posttest terhadap 92 responden yang terbagi atas 46 responden kelompok Intervensi dan 46 responden kelompok kontrol, dengan purposive sampling. Kelompok intervensi diajarkan latihan pernafasan relaksasi dan pemberian leaflet selama 4 minggu pada bulan April-Juli 2018 di Rumah Sakit Siloam Manado. Hasil : Mayoritas pasien kemoterapi 69,6\% berusia 45-65 tahun, 54,3\% pasien lama terdiagnosa kanker $\leq 1$ tahun dan 79,3\% jenis pemberian kemoterapi kombinasi. Hasil uji Wilcoxon menunjukan ada perbedaan signifikan sebelum dan sesudah intervensi terhadap kelelahan ( $p$ value $=0,00$ ), dengan rerata skor penurunan 21,97\% pada kelelahan. Hasil uji Mann Whitney menunjukan perbedaan signifikan kelelahan antara kelompok intervensi dan kontrol ( $p$ value $=0,00$ ). Hasil regresi logistik multivariat menunjukan terdapat pengaruh intervensi latihan pernafasan relaksasi terhadap kelelahan ( $p$ value $<0,00$ ) dan Latihan pernafasan relaksasi dapat menurunkan 60,46 kali kelelahan pada pasien kanker dengan kemoterapi. Kesimpulan : Latihan pernafasan relaksasi dapat menurunkan kelelahan pada pasien kanker yang menjalani kemoterapi di Rumah Sakit Siloam 
Manado. Saran : Penelitian ini merekomendasikan penerapan latihan pernafasan relaksasi untuk menjadi latihan rutin pasien kanker selama menjalani kemoterapi dalam meminimalkan kelelahan.

Kata Kunci: Latihan Pernafasan Relaksasi, Kelelahan, Kemoterapi, Kanker

Background : Cancer patients with chemotherapy experience fatigue as cancer effects and cell destruction due to the toxicity of chemotherapy drugs. Objective : Determine the effectiveness of relaxation breathing exercises to fatigue cancer patients who undergoing chemotherapy. Method : This research used quasi experiment pretest and posttest method. There were 92 respondents who examined using purposive sampling technique and divided into 46 respondents as intervention group and 46 respondents as control group. Relaxation breathing exercise was given four weeks for intervention group on April-July 2018 in Siloam Hospital Manado. Result : The majority of cancer patients were age 45-65 years 69,9\%, 54,3\% were diagnosed cancer $\leq 1$ year and $79,3 \%$ received combination chemotherapy. The result of Wilcoxon test revealed there was significant difference before and after intervention to fatigue ( $p$ value $=0,00)$, with mean rank of reduction $21,97 \%$ on fatigue. The result of Mann Whitney test revealed that there was significant difference in fatigue between intervention and control groups ( $p$ value $=0,00$ ). Multivariate logistic regression revealed that there was an effect of relaxation breathing exercise on fatigue ( $p$ value $=0,00$ ) andrelaxation breathing exercise may reduce 60,46 times of fatigue on patients who undergoing chemotherapy. Conclusion : Relaxation Breathing Exercise can reduce fatigue in cancer patients who undergoing chemotherapy in Siloam Hospital Manado. It is recommended to perform relaxation breathing exercise as a routine exercise for cancer patients during chemotherapy to minimize fatigue.

Keywords : Relaxation Breathing Exercise, Fatigue, Chemotherapy, Cancer 


\section{PENDAHULUAN}

Kanker merupakan suatu kelompok penyakit yang

dikarakteristikkan sebagai pertumbuhan yang tidak terkontol dan tidak normal dari sel (Lewis et al, 2017). Penyakit kanker merupakan salah satu penyebab angka kejadian dan kematian utama di seluruh dunia, dengan sekitar 14 juta kasus baru dan 8,2 juta kematian yang mempengaruhi populasi dunia. Lebih dari $60 \%$ kasus baru dan sekitar 70\% kematian akibat kanker di dunia setiap tahunnya terjadi di Afrika, Asia dan Amerika Tengah dan Selatan. Berdasarkan data Global Burden of Cancer (2012) terdapat 14.067.894 kasus baru kanker dan 8.201.575 kematian akibat kanker di seluruh dunia. Diperkirakan kasus kanker tahunan akan meningkat dari 14 juta pada 2012 menjadi 22 juta dalam dua dekade berikutnya (WHO, 2014; Kemenkes, 2015). Menurut Riset Kesehatan Dasar tahun 2013, prevalensi penyakit kanker di Indonesia secara keseluruhan berada pada 1,4\%o, dimana Provinsi Sulawesi Utara sendiri berada pada presentase 1,7 \%o (Kemenkes, 2015).Kanker yang diketahui sejak dini memiliki kemungkinan untuk mendapatkan penanganan lebih baik.

Pengobatan kanker terdiri atas radioterapi, kemoterapi, pembedahan, bioterapi dan transplantasi sum-sum tulang (Langhorne et al, 2011). Salah satu terapi yang paling sering digunakan adalah kemoterapi, terutama terhadap kanker sistemik dan kanker dengan metastasis klinis ataupun subklinis (Desen, 2008).Kemoterapi merupakan penggunaan preparat antineoplastik yang digunakan sebagai upaya untuk membunuh sel-sel tumor 
dengan mengganggu fungsi dan reproduksi selular (Smeltzer \& Bare, 2010). Meskipun sering menjadi terapi pilihan utama, kemoterapi menyebabkan banyak efek samping diantaranya mual muntah, kelelahan, gangguan keseimbangan cairan elektrolit dan stomatitis. Kerusakan pada folikel rambut yang mengakibatkan kebotakan pada klien (alopesia). Kondisi-kondisi ini dapat menjadi sesuatu yang membuat cemas dan stres pada pasien yang terkadang membuat pasien memilih untuk menghentikan siklus terapi sehinggaberpotensi mempengaruhi harapan hidup dimasa depan. (Hesket, 2008; Smeltzer \& Bare, 2010).

Kelelahan (fatigue) adalah salah satu keluhan yang paling sering dan mengganggu pasien kanker (60-90\%) dan lebih dari $80 \%$ pasien yang menjalani pengobatan seperti kemoterapi mengalami hal ini (Hassan \& Campos, 2014).Kelelahan dan mempengaruhi banyak aspek kehidupan pasien baik fisik, mental, dan emosional dan memiliki dampak negatif yang signifikan pada fungsi fisik pasien dan kualitas hidup keseluruhan pasien kanker sehingga dapat mempengaruhi juga pekerjaan, seksualitas dan kehidupan keluarga mereka sehari-hari (Weis, 2011).Dalam mengembalikan perubahan akibat kanker dan pengobatannya dalam hal ini kelelahan, intervensi yang tepat melalui pendekatan multi disiplin (seperti, latihan fisik, relaksasi, pendidikan, konseling) menunjukan bukti yang signifikan (de Boer et al, 2011 dalam, Stanton, Rowland \& Ganz, 2015).

Relaksasi merupakan salah satu intervensi yang tepat dalam 
mengembalikan perubahan akibat kanker dan pengobatannya dalam hal ini kelelahan, (de Boer et al, 2011 dalam, Stanton, Rowland \& Ganz, 2015).Relaksasi merupakan salah satu bentuk mind body therapy dalam Complementary and Alternatif Therapy (Black \& Hawks, 2014).Menurut Sood, et al (2007), Relaxation Breathing Exercise atau dalam bahasa Indonesia diartikan sebagai Latihan pernafasan relaksasimerupakan salah satu terapi komplementer pada pasien kanker dengan kelelahan.Latihan pernafasan relaksasi merupakan suatu tindakan/intervensi yang terdiri dari latihan fisik yang dikombinasikan dengan relaksasi pernapasan (Kim \& Kim, 2005).Penelitian Kim \& Kim (2005) menunjukan bahwa Latihan Pernafasan Relaksasi mampu menurunkan kelelahan pada pasien kanker yang menjalani haemopoietic stem cell transplantation.

Rumah Sakit Siloam Manado adalah rumah sakit tipe B di Sulawesi Utara yang telah mengembangkan kemoterapi. Tindakan yang dilakukan pada pasien yang mengalami kelelahan yaitu dianjurkan untuk istirahat. Selain itu, tindakan mandiri keperawatan atau tindakan komplementer seperti latihan pernafasan relaksasi belum diaplikasikan oleh perawat dalam tindakan keperawatan harian.

Berdasarkan hal tersebut peneliti bermaksud untuk melakukan penelitian tentang efektivitas latihan Pernafasan Relaksasi terhadap kelelahanpada pasien kanker yang menjalani kemoterapi di Rumah Sakit Siloam Manado. 


\section{METODE PENELITIAN}

Penelitian ini adalah analitik observasional dengan desain yang digunakan adalah cross sectional study yaitu suatu penelitian untuk mempelajari dinamika korelasi antara sebab dan akibat dengan efek dengan cara pendekatan, observasi, atau pengumpulan data sekaligus pada saat itu juga (Notoatmodjo, 2007).

Penelitian ini telah dilaksanakan di Ruang rawat inap RSUD Kabupaten Wakatobi pada tanggal 20 Juli sampai dengan 15 Agustus 2018. Besar sampel sebanyak 55 responden menggunakan teknik proportional stratifield random sampling yaitu penarikan sampel secara proporsional (Arikunto, 2016).

Data yang digunakan dalam penelitian ini adalah data primer dan data sekunder. Data primer adalah data yang diperoleh langsung melalui wawancara dari responden yakni pengetahuan tentang PPIRS, dan perilaku perawat dalam mencegah infeksi nosokomial di Rumah Sakit. Sedangkan data sekunder diperoleh di RSUD Kabupaten Wakatobi dan Dinas Kesehatan Provinsi Sultra.

Instrumen yang digunakan dalam penelitian ini berupa kuesioner yang disadur dari penelitian sebelumnya (Herpan, 2012) yang telah melalui uji validitas dan reabilitas yaitu pengetahuan tentang PPIRS, dan perilaku perawat dalam mencegah infeksi di Rumah Sakit.

Penelitian ini menggunakan analisis univariat dan bivariat. Analisis univariat dilakukan untuk melihat distribusi frekuensi baik dari variabel independen maupun variabel dependen dan dilakukan 
dengan menggunakan program SPSS versi 19. Analisis bivariat

dilakukan untuk melihat hubungan antara variabel dependen dan independen dengan menggunakan uji statistik chi square $\left(\mathrm{X}^{2}\right)$ tabel kontigensi $2 \times 2$ dengan tingkat kepercayaan $95 \%(\alpha=0,05)$. Analisis bivariat akan dilakukan dengan menggunakan program SPSS versi 19.0. Jika hasil analisis Chi Square $\left(X^{2}\right)$ tidak memenuhi syarat maka dilanjutkan dengan uji fisher exact test.

\section{HASIL DAN PEMBAHASAN}

Tabel 1. Distribusi Pasien Kemoterapi Berdasarkan Jenis Kelamin, Usia, Pendidikan, dan Lama Terdiagnosa Medis

\begin{tabular}{cccc}
\hline Usia & & Jumlah & $\%$ \\
\hline 31-44 tahun & & 15 & 16,3 \\
45-65 tahun & & 64 & 69,6 \\
$>65$ tahun & & 13 & 14,1 \\
& Total & 92 & 100 \\
Lama terdiagnosa medis & & & \\
$\leq 1$ tahun & & 50 & 54,3 \\
$>1$ tahun & & 42 & 45,7 \\
& Total & 92 & 100 \\
Jenis pemberian kemoterapi & & & 20,7 \\
Tunggal & & 19 & 79,3 \\
Kombinasi & & 73 & 100
\end{tabular}

(Sumber: Data Primer diolah berdasarkan data yang diperoleh)

Berdasarkan tabel satu, Pasien kanker yang menjalani kemoterapi mayoritas berusia 45-65 tahun, lama terdiagnosa medis sebagian besar $\leq 1$ tahun dan jenis pemberian kemoterapi sebagian besar merupakan pemberian kemoterapi kombinasi.

Tabel 2. Hasil Uji Wilcoxon Skor Kelelahan Sebelum dan Sesudah Intervensi

Variabel Rerata skor pre- $\quad$ Rerata skor posttest test 
Kelelahan

Intervensi

28,67

29,54

22,37

,000

Kontrol

34,96

,000

(Sumber: Data Primer diolah berdasarkan data yang diperoleh)

Berdasarkan tabel dua, hasil penelitian menunjukan bahwa terdapat penurunan rerata skor keadaan kelelahan setelah diberikan intervensi dengan $p=0,000$, dibandingkan kelompok kontrol yang mengalami peningkatan rerata skor kelelahan saat post test walaupun dengan $p=0,000$.

Tabel 3. Hasil Uji ManWhitney Skor Kelelahan Kelompok Intervensi dan Kontrol

\begin{tabular}{cccc}
\hline \multirow{2}{*}{ Variabel } & \multicolumn{2}{c}{ Rerata Skor } & \multirow{2}{*}{$\mathrm{P}$} \\
\cline { 2 - 3 } & Intervensi & Kontrol & \\
\hline Kelelahan & 64,9 & 28,91 &, 000 \\
\hline
\end{tabular}

(Sumber : Data Primer diolah berdasarkan data yang diperoleh)

Hasil penelitian menunjukan bahwa terdapat lebih banyak penurunan rerata skor kelelahan pada kelompok intervensi dibandingkan kelompok kontrol dengan $p=0,000 ; p<0,005$.

Hubungan Latihan Pernafasan Relaksasi dan Variabel Perancu terhadap Kelelahan

Berdasarkan hasil analisa Chi-Square latihan pernafasan relaksasi memiliki pengaruh terhadap kelelahan dengan $p=0,000$ dan juga dengan jenis pemberian kemoterapi dengan $p=0,012$. Berbeda dengan usia $(p=0,409)$ dan lama terdignosa medis $(p=0,566)$ dengan $p>0,05$.

Hal diatas menunjukan bahwa terdapat dua variable yang memiliki korelasi yang kuat $(p=0,250)$ yaitu variabel latihan 
pernafasan relaksasi $(p=0,000)$ dan variabel usia $(p=0,012)$, sehingga dapat menjadi kandidat untuk uji regresi logistik multivariate.

Pengaruh Latihan Pernafasan Relaksasi dan Variabel Perancu terhadap Kelelahan

Pengaruh latihan pernafasan relaksasi dan variabel perancu terhadap kelelahan dapat dilihat pada tabel dibawah ini.

Tabel 4 . Hasil Regresi Logistik Multivariat Metode Backward LR

\begin{tabular}{llccc}
\hline & & B & Sig. & Exp (B) \\
\hline Step 0 & Constant &, 131 &, 532 & 1,140 \\
\hline Step 1 & Jenis Pemberian Kemoterapi & 1,569 &, 068 & 4,803 \\
\hline \multirow{2}{*}{ Latihan } & 4,102 &, 000 & 60,462 \\
\hline & Constant & 1,115 &, 474 & 3,050
\end{tabular}

(Sumber: Data Primer diolah berdasarkan data yang diperoleh)

Hasil ini menunjukan adanya pengaruh intervensi latihan pernafasan relaksasi terhadap kelelahan pasien kemoterapi ( $\boldsymbol{p}_{\text {value }}$ $0,00 ;<0.05)$. Penurunan kelelahan pasien kemoterapi setelah mengikuti latihan pernafasan relaksasi sebanyak 60,46 kali dibandingkan dengan pasien kemoterapi yang tidak melakukan latihan pernafasan relaksasi. Selain itu, tidak terdapat terdapat variabel perancu yang mempengaruhi penurunan kelelahan.

\section{PEMBAHASAN}

Hasil penelitian menunjukan bahwa terdapat perbedaan yang signifikan sebelum dan sesudah dilakukan tindakan latihan pernafasan relaksasi. Hal ini sejalan dengan penelitian yang 
dilakukan oleh Van Waart, et al (2015) kepada 230 pasien kanker payudara yang menjalani kemoterapi menujukan keefektifan pada kelompok intervensi yang melakukan latihan fisik harian selama \pm 30 menit per hari dalam 5 hari seminggu selama 3 minggu untuk meminimalkan kelelahan $(p=0,001)$. Penelitian ini juga didukung oleh penelitian Cheville et al (2013) yang menunjukan perbedaan kelelahan antara kelompok intervensi dibandingkan kelompok kontrol setelah dilakukan home based exercise selama 8 minggu ( $p=$ $0,02)$.

Pengaruh latihan pernafasan relaksasi seperti latihan fisik terhadap kelelahan dibuktikan melalui penelitian-penelitian yang menunjukan terdapat perbedaan yang signifikan antara kelompok intervensi dan kelompok kontol (Kim \& Kim, 2005, Van Waart, et al, 2015; Cheville et al, 2013; Cramp \& Byron-Daniel, 2012; Velthuis et al, 2010). Selain teori disregulasi serotonin (5-hydroxytryptamine), Latihan fisik mempromosikan penggunaan oksigen secara efisien, menurunkan denyut jantung dan tekanan darah, meningkatkan fleksibilitas, meningkatkan kekuatan (otot dan tulang) dan mendorong tidur lebih nyenyak (Kirshbaum, 2010).

Latihan fisik dalam intervensi latihan pernafasan relaksasi memiliki pengaruh besar dalam mengurangi kelelahan. Cramp \& Byron-Daniel (2012) melalui tinjauan literaturnya mengungkapkan bahwa terdapat penurunan kelelahan yang signifikan secara statistik setelah mengikuti program latihan fisik baik selama mengikuti terapi/pengobatan kanker. Latihan fisik seperti aerobik juga mempunyai pengaruh yang signifikan terhadap kelelahan dan 
meningkatkan kapasitas fisik (McMillan \& Newhouse, 2011;

Velthuis et al, 2010). Teori disregulasiserotonin otak (5hydroxytryptamine) dan peningkatan kapasitas fisik melalui latihan fisik menjadi faktor yang berpengaruh terhadap penurunan kelelahan ini (Horneber et al, 2012; Velthuis et al, 2010).

Pasien dengan kanker melewati fase beradaptasi terhadap kelelahan yang kemudian berdampak pada penurunan aktivitas, istirahat perubahan perilaku, stress maupun kecemasan. Mekanisme pengaruh latihan fisik pada kelelahan dapat dilihat dari kanker dan/atau pengobatan kanker yang menyebabkan kenaikan tingkat serotonin otak (5-HT) dan/atau peningkatan regulasi populasi reseptor 5-HT, sehingga mengurangi pengaturan somatomotor, dimodifikasi di hipotalamus bagian pituitary adrenal yaitu pada fungsi sumbu (HPA) dan sensasi kapasitas berkurang untuk melakukan pekerjaan fisik. Peningkatan konsentrasi 5-HT dapat mengakibatkan kelelahan fisik dan mental pada pasien kanker. Studi pada pasien dengan sindrom kelelahan kronis telah menunjukkan tingkat plasma mengangkat triptofan yang berpotensi menyebabkan tingkat 5-HT. Langkah pembatasan untuk sintesis dari 5-HT di otak adalah transportasi triptofan ke dalam otak. Latihan fisik dapat meningkatkan konsentrasi asam lemak bebas plasma yang menggusur triptofan dari albumin, sehingga menghasilkan triptofan terikat lebih tersedia (Horneber et al, 2012).

Selain itu, dasar pemikiran yang mendukung latihan fisik pada kelelahan kanker didasarkan pada proposisi bahwa efek gabungan 
dari penyakit, intervensi medis dan tingkat penurunan aktivitas selama pengobatan menyebabkan penurunan kapasitas fisik (Lucia et al, 2003 \& Irwin et al, 2004 dalam Velthuis et al, 2010). Sebuah beban kerja sekitar $40 \%$ dari penyerapan oksigen maksimal (VO2peak) dapat dipertahankan sepanjang hari tanpa kelelahan dini. Saat kapasitas fisik berkurang, beban kerja dari aktivitas fisik normal menuntut persentase kapasitas fisik yang relatif lebih tinggi, sehingga mengakibatkan kelelahan dini.Latihan fisik dengan frekuensi, intensitas dan durasi yang cukup akan meningkatkan kapasitas fisik melalui peningkatan curah jantung dan peningkatan kapilarisasi, peningkatan jumlah mitokondria dan Aktivitas mitokondria di perifer, sehingga bisa menyebabkan pengurangan atau pencegahan kelelahan pada pasien kanker (Velthuis et al, 2010).

Latihan pernafasan relaksasi membantu pasien beradaptasi secara fisiologis seperti mengurangi kelelahan dan tubuh menjadi rileks. Perbedaan sebelum dan setelah dilakukan latihan pernafasan relaksasi kepada pasien tampak saat pasien mengatakan bahwa setelah melakukan latihan selama 4 minggu tubuh terasa lebih bugar dan sehat, mampu melakukan aktivitas harian dengan lebih efektif dan perasaan terasa lebih menyenangkan.

\section{KESIMPULAN}

Latihan Pernafasan Relaksasi berpengaruh terhadap penurunan kelelahan pasien kanker yang menjalani kemoterapi dengan $p=0,000$. Variabel perancu seperti jenis pemberian 


\section{DAFTAR PUSTAKA}

kemoterapi juga berpengaruh terhadap kelelahan $(p=0,012)$.

Berbeda halnya dengan usia dan lama terdiagnosa kanker yang tidak memiliki pengaruh terhadap penurunan kelelahan $(p>0,05)$. Pasien yang melakukan Latihan Pernafasan Relaksasi mempunyai kemungkinan penurunan kelelahan 60,46 kali dibandingkan pasien yang tidak melakukan latihan.

Latihan pernafasan relaksasi dianjurkan untuk menjadi latihan rutin dirumah setiap hari sebagai pendamping selama kemoterapi untuk meminimalkan kelelahan pasien kanker yang menjalani kemoterapi.

American Cancer Society. (2017). Cancer Facts \& Figures 2017. American Cancer Society, Inc.

Black, Joyce M \& Hawks, Jane H. (2014). Medical Surgical Nursing: Clinical Management fot Positive Outcomes $8^{\text {th }}$ Edition. Editor Bahasa Indonesia: Susila, Akila.,dkk. Singapore: Elsevier Cheville, A. L., Kollasch, J., Vandenberg, J., Shen, T., Grothey, A., Gamble, G., \& Basford, J. R. (2013). A Home-Based Exercise Program to Improve Function, Fatigue, and Sleep Quality in Patients With Stage IV Lung and Colorectal Cancer: A Randomized Controlled Trial. Journal of Pain and Symptom Management, 45(5), 811-821.

Cramp, F. A. \& Byron-Daniel, J. Z. (2012). Exercise for the management of cancer-related fatigue in adults ( Review ). The Cochrane Library, 11.

Desen, W. (2008). Buku Ajar Onkologi Klinis. Edisi II. Balai Penerbit FK-UI, Jakarta.

Hassan, B., J., \& Campos, M., P. (2014). Cancer-Related Fatigue; The Handbook of Behavioral Medicine, First Edition. John Wiley \& Sons, Inc., 105-123.

Hesketh, P. J. (2008). Chemotherapy-Induced Nausea and Vomiting, N Eng J Med, Caritas St. Elizabeth's Medical Center, Boston, England. 
Horneber, M., Fischer, I., Dimeo, F., Rüffer, J.U., Weis, J. (2012). Cancer-Related Fatigue Epidemiology, Pathogenesis, Diagnosis, and Treatment. Deutsches Ärzteblatt International; 109(9): 161-72

Kemenkes. (2015). Buletin Jendela Data\& Informasi Kesehatan. Situasi Penyakit Kanker, hal. 1-35

Kim, S., \& Kim, H. (2005). Effects of a Relaxation Breathing Exercise on Fatigue in Haemopoietic Stem Cell Transplantation Patients. Journal of Clinical Nursing, 14(1), 51-55.

Kirshbaum, M. (2010). Cancer-related fatigue: a review of nursing interventions. British Journal of Community Nursing, 15(5), 214-219.

Langerhone, M., Fulton, J., Otto, S.E. (2011). Oncology Nursing; Fifth Edition. Reprinted Edition. Singapore; Elsevier

Lewis, et.al. (2017). Medical Surgical Nursing. Assessment and Management of Clinical Problems. Tenth Edition. Volume 1. St. Louis, Missouri: Elsevier Mosby.

McMillan, E. M., \& Newhouse, I.J. (2011). Exercise is an effective treatment modality for reducing cancer-related fatigue and improving physical capacity in cancer patients and survivors: a meta-analysis. Applied Physiology Nutrition and Metabolism. Vol 36: 892-903

Smeltzer \& Bare. (2010). Brunner \& Suddarth's Textbook of Medical-Surgical Nursing. Philadelphia; Lippincot Williams \& Wilkins.

Sood, A., Barton, D. L., Bauer, B. A., \& Loprinzi, C. L. (2007). A critical review of complementary therapies for cancer-related fatigue. Integrative Cancer Therapies, 6(1), 8-13.

Stanton, A. L., Rowland, J., H \& Ganz, P. A. (2015). Life after diagnosis and treatment of cancer in adulthood: Psychosocial Oncology Research, 159-174

Van Waart, H, \& Stuiver, M. M. (2017). Effect of Low-Intensity Physical Activity and Moderate- to High-Intensity Physical Exercise During Adjuvant Chemotherapy on Physical Fitness, Fatigue, and Chemotherapy Completion Rates: Results of the 
PACES Randomized Clinical Trial. Journal Of Clinical Oncology ,33(17).

Velthuis, M. J., Agasi-Idenburg, S.C., Aufdemkampe, G., Wittink, H.M. (2010) The Effect of Physical Exercise on Cancer-related Fatigue during Cancer Treatment: a Meta-analysis of Randomised Controlled Trials. Clinical Oncology, (22) 208-221

Weis, J. (2011). Cancer-related fatigue: Prevalence, assessment and treatment strategies. Expert Review of Pharmacoeconomics and Outcomes Research, 11(4), 441-446.

WHO. (2014). World Cancer Report 2014. International Agency for Research on Cancer; France 